\title{
Corticotropin-releasing hormone stimulates expression of leptin, 11 beta-HSD2 and syncytin-1 in primary human trophoblasts
}

\author{
Fabian B Fahlbusch ${ }^{1 *}$, Matthias Ruebner ${ }^{2}$, Gudrun Volkert ${ }^{1}$, Ramona Offergeld ${ }^{1}$, Andrea Hartner ${ }^{1}$, \\ Carlos Menendez-Castro ${ }^{1}$, Reiner Strick ${ }^{2}$, Manfred Rauh ${ }^{1}$, Wolfgang Rascher ${ }^{1}$ and Jörg Dötsch ${ }^{3}$
}

\begin{abstract}
Background: The placental syncytiotrophoblast is the major source of maternal plasma corticotropin-releasing hormone $(\mathrm{CRH})$ in the second half of pregnancy. Placental $\mathrm{CRH}$ exerts multiple functions in the maternal organism: It induces the adrenal secretion of cortisol via the stimulation of adrenocorticotropic hormone, regulates the timing of birth via its actions in the myometrium and inhibits the invasion of extravillous trophoblast cells in vitro. However, the auto- and paracrine actions of $\mathrm{CRH}$ on the syncytiotrophoblast itself are unknown. Intrauterine growth restriction (IUGR) is accompanied by an increase in placental CRH, which could be of pathophysiological relevance for the dysregulation in syncytialisation seen in IUGR placentas.

Methods: We aimed to determine the effect of $\mathrm{CRH}$ on isolated primary trophoblastic cells in vitro. After $\mathrm{CRH}$ stimulation the trophoblast syncytialisation rate was monitored via syncytin-1 gene expression and beta-hCG (beta-human chorionic gonadotropine) ELISA in culture supernatant. The expression of the IUGR marker genes leptin and 11 beta-hydroxysteroid dehydrogenase 2 (11 beta-HSD2) was measured continuously over a period of $72 \mathrm{~h}$. We hypothesized that $\mathrm{CRH}$ might attenuate syncytialisation, induce leptin, and reduce 11 beta-HSD2 expression in primary villous trophoblasts, which are known features of IUGR.
\end{abstract}

Results: $\mathrm{CRH}$ did not influence the differentiation of isolated trophoblasts into functional syncytium as determined by beta-hCG secretion, albeit inducing syncytin-1 expression. Following syncytialisation, $\mathrm{CRH}$ treatment significantly increased leptin and 11 beta-HSD2 expression, as well as leptin secretion into culture supernatant after $48 \mathrm{~h}$.

Conclusion: The relevance of $\mathrm{CRH}$ for placental physiology is underlined by the present in vitro study. The induction of leptin and 11 beta-HSD2 in the syncytiotrophoblast by CRH might promote fetal nutrient supply and placental corticosteroid metabolism in the phase before labour induction.

Keywords: CRH, leptin, 11 beta-HSD2, Syncytin-1, Trophoblast, Syncytiotrophoblast, Placenta

\section{Background}

As part of the neuroendocrine system, the hypothalamopituitary-adrenal axis controls a wide range of body functions in humans. Hypothalamic corticotropin-releasing hormone $(\mathrm{CRH})$ acts via its two receptors $\mathrm{CRH}-\mathrm{R} 1$ and $\mathrm{CRH}-\mathrm{R} 2$ to control stress reaction, autonomic functions, behavioural response, appetite, metabolism and the immune system.

\footnotetext{
* Correspondence: fabian.fahlbusch@uk-erlangen.de

1 Department of Pediatrics and Adolescent Medicine, University of Erlangen-Nürnberg, Erlangen, Germany

Full list of author information is available at the end of the article
}

Since its discovery in placental extracts in 1982 [1] it has become evident, that $\mathrm{CRH}$ and the related peptide urocortin [2] also exert important functional roles in human reproductive physiology [3,4]. CRH and its receptors are present in ovaries [5], endometrium [6], decidua [7], myometrium [8] and in the placenta (syncytiotrophoblast, chorion and amnion) $[9,10]$. The placental syncytiotrophoblast is a major source of plasma CRH in the maternal circulation in the second half of pregnancy [11]. Multiple isoforms of the CRH receptors CRH-R1 and CRH-R2 were identified in the placental trophoblast $[9,10]$ and myometrium $[12,13]$ throughout 
gestation. Hence differential local effects on fetal and maternal intra-uterine tissues are conceivable. The effects of placental $\mathrm{CRH}$ have been intensively studied indirectly via the action of the cortisol proxys leptin and $11 \beta$-HSD2 $[14,15]$ and directly at the placental bed, where it plays an important role in the timing of birth in humans [16]. CRH interacts with progesterone to enhance the contractile response of the myometrium $[16,17]$ and regulates the vascular tonus in the fetoplacental circulation through the nitric oxide (NO)/cGMP pathway $[18,19]$. Bamberger et al. [20] have recently shown, that $\mathrm{CRH}$ inhibits extravillous trophoblast (EVT) invasion by decreasing the expression of CEACAM1 via signalling through CRH-R1. There is growing evidence that a dysregulation of spiral artery invasion by EVT in the first trimester is a process contributing to the vascular resistance observed in the pregnancy complications preeclampsia and intrauterine growth restriction (IUGR) in late pregnancy $[21,22]$. In line with this finding, we and others have previously shown that placental CRH expression and CRH in maternal plasma are significantly elevated in IUGR [23-26]. IUGR is further pathophysiologically characterized by a reduction in trophoblastic syncytialisation rate [27], increased leptin [28] and reduced $11 \beta$-HSD2 [29] expression.

Although it is known that the syncytiotrophoblast is a major source of $\mathrm{CRH}$ in the second half of pregnancy, the role of $\mathrm{CRH}$ on the process of cytotrophoblastic syncytialisation and on endocrine hormone regulation in the syncytiotrophoblast is unknown so far.

To further investigate local actions of $\mathrm{CRH}$ on trophoblast function, we sought to determine its influence on the syncytialisation of isolated primary villous trophoblastic cells and on the expression of leptin and $11 \beta$-HSD2. We found that CRH induced leptin and $11 \beta-$ HSD2 expression, without affecting syncytialisation of trophoblastic cells.

\section{Methods}

\section{Placental collection and tissue culture}

Six term placentas from women with singleton uncomplicated pregnancies were collected immediately after placental delivery. Elective caesarean section delivery was performed and birth weight was $>10^{\text {th }}$ percentile according to Voigt et al. [30]. Primary human cytotrophoblasts were isolated from the placentas using the established trypsine-DNAse-dispase/percoll method as initially described by Kliman et al. [31], with additional previously published modifications [32,33]. The purity of trophoblastic cells was routinely controled by multiple FACS analysis (FACSCalibur, BD Biosciences), as described previously [33], providing at least $90 \%$ cytotrophoblasts. In short, we determined that $10-13.3 \%$ of the fractions were HLA-A,B,C + (mainly mononuclear blood cells and fibroblasts) and 86.6-90\% HLA-A,B,C negative. Additionally, fractionated cells were $2.4-4.5 \%$ CD $45+$ (mononuclear blood cells) and 95.5-97.6\% CK7+ (epithelial marker). Antibodies used: CK7/PE (clone 5 F282), Santa Cruz Bio., Heidelberg, Germany (1:20); HLA-A,B, C/PE (cloneW6/32), Biolegend, Uithoorn, Netherlands (1:10); CD45/FITC, Miltenyi Biotec, Berg. Gladbach, Germany (1:10). Hence $86.6-90 \%$ of the fractionated cells were trophoblastic cells and $10-13.3 \%$ nontrophoblastic cells. Multinucleated fractured syncytial fragments were identified via their DNA-content using propidium iodide staining (Sigma-Aldrich Chemie, Munich, Germany; $50 \mu \mathrm{g} / \mathrm{ml}$ ), specific for DNA content. All fractured syncytial cellular fragments, non-adherent cells and debris were removed initially after $4 \mathrm{~h}$ and then every $24 \mathrm{~h}$ with a medium change [34]. Cells were subsequently seeded into 6-well Falcon plates (Becton Dickinson, Heidelberg, Germany) at a density of $3 \times 10^{5}$ cells $/ \mathrm{cm}^{2}$ and maintained in Earl's medium 199 (PAA Laboratories, Linz, Austria) supplemented with 10\% fetal calf serum (PAA Laboratories), $20 \mathrm{mM}$ Hepes (Sigma-Aldrich), $0.5 \mathrm{mM}$ L-glutamine (Gibco Invitrogen, Karlsruhe, Germany), penicillin $(10 \mathrm{U} / \mathrm{ml})$, streptomycin $(10 \mathrm{mg} / \mathrm{ml})$, and fungizone $(0.25 \mathrm{mg} / \mathrm{ml})$ (SigmaAldrich, Gibco Invitrogen, respectively). Cultures were grown at $37{ }^{\circ} \mathrm{C}$ under normoxia with $95 \%$ air, $5 \% \mathrm{CO}_{2}$ in a humidified atmosphere using a Forma Scientific incubator (Fisher Scientific, Schwerte, Germany) as described in detail previously [33]. After incubation for $24 \mathrm{~h}$, trophoblastic cells were stimulated with $0.5,1.0$ and $2.0 \mu \mathrm{g} / \mathrm{ml}$ (equivalent to $100,200,400 \mathrm{nM}$, respectively) $\mathrm{CRH}$ (Bachem, Weil am Rhein, Germany) for 6, $12,24,48$ and $72 \mathrm{~h}$. This range of concentrations was chosen, as it has been described to exert biological effects on trophoblasts [20]. Our pilot study showed no difference of repetitive stimulation vs. single application of $\mathrm{CRH}$ to the cell culture, with significant changes in gene expression between vehicle and CHR-treated groups starting with $48 \mathrm{~h}(1.0$ and $2.0 \mu \mathrm{g} / \mathrm{ml} \mathrm{CRH})$ for the analysed genes. $72 \mathrm{~h}$ were chosen as the maximum observational period, because our previous experiments have shown that cytotrophoblast viablitiy steadily decreases afterwards. Hence for illustration of group differences the time-points of $48 \mathrm{~h}$ and $72 \mathrm{~h}$ and $\mathrm{CRH}$ concentrations of $1.0 \mu \mathrm{g} / \mathrm{ml}$ and $2.0 \mu / \mathrm{ml}$ are displayed in the results section only. Cultured trophoblasts as well as culture supernatants were collected at the time-points described above, snap frozen and stored at $-80^{\circ} \mathrm{C}$ until further processing. All experiments were assayed in triplicate and were repeated using cells from different placentas.

\section{Ethics}

The study was reviewed and approved by the Ethics Committee of the Medical Faculty of the University of 
Erlangen-Nürnberg (\#2625 02/28/02). Written informed consent was obtained from all subjects.

RNA isolation and reverse transcription-polymerase chain reaction (RT-PCR)

Total RNA was isolated from primary human trophoblasts using TRIzol reagent (Gibco Invitrogen) as recommended by the manufacturer. RNA was quantified by absorbance at $260 \mathrm{~nm}$ and the quality of RNA was confirmed using a $1 \%$ agarose gel. After DNase treatment, $1.0 \mathrm{mg}$ RNA was transcribed into cDNA using M-MLVRT (Promega, Madison, WI, USA) and Oligo dT-primer (MWG-Biotech AG, Ebersberg, Germany). DNase treatment and cDNA synthesis were carried out as previously $[33,35]$.

\section{SYBR-Green based real-time PCR $\left(2^{-\Delta \Delta C T}-\right.$ method)}

As previously described [14] the mRNA expression of leptin, 11ß-HSD2, Syncytin-1, CRH-R1 and CRH-R2 were quantified by normalising to the house-keeping gene hypoxanthine guanine phosphoribosyl transferase (HPRT) and confirmed with r18S as a second housekeeper, yielding the same results. Commercial reagents (Absolute Blue SYBR Green master mix, ABgene, UK) and conditions were applied according to the manufacturer's protocol. Serial dilutions of one of the samples served as reference providing relative quantification of the unknown samples. Sequences of primers and probes are listed in Table 1.

\section{Determination of $\beta$-hCG, leptin and LDH concentration in the supernatant}

The concentration of $\beta$-human chorionic gonadotropine $(\beta-\mathrm{hCG})$ in the supernatants of trophoblastic cells was determined by the use of an UniCel DxI 600 Access Immunoassay System (Beckman Coulter, Krefeld, Germany). The concentration of leptin in the supernatants of

Table 1 Primer sequences

\begin{tabular}{|c|c|c|}
\hline & Forward $\left(5^{\prime}-3^{\prime}\right)$ & Reverse $\left(5^{\prime}-3^{\prime}\right)$ \\
\hline HPRT & CCGGCTCCGTTATGGC & $\begin{array}{l}\text { GGTCATAACCTGGTTCA- } \\
\text { TCATCA }\end{array}$ \\
\hline r18s & $\begin{array}{l}\text { GCAATTATTCCCCATG- } \\
\text { AACG }\end{array}$ & $\begin{array}{l}\text { GGCCTCACTAAACCAT- } \\
\text { CCAA }\end{array}$ \\
\hline Leptin & $\begin{array}{l}\text { ACAATTGTCACCAGGA- } \\
\text { TCAATGAC }\end{array}$ & $\begin{array}{l}\text { TCCAAACCGGTGACTT- } \\
\text { TCTGT }\end{array}$ \\
\hline $11 \beta-H S D 2$ & $\begin{array}{l}\text { CATCACCGGCTGTGAC- } \\
\text { TCTG }\end{array}$ & CGGCAGCCGCATGTTAG \\
\hline $\begin{array}{l}\text { CRH-R1 } \\
\text { alpha }\end{array}$ & $\begin{array}{l}\text { CTACATGCTGTTCTTCG- } \\
\text { TCAATCC }\end{array}$ & GGCAGAACGGACCTGGAA \\
\hline $\mathrm{CRH}-\mathrm{R} 2$ & $\begin{array}{l}\text { TCCAGTACAGGAAGG- } \\
\text { CAGTGAA }\end{array}$ & $\begin{array}{l}\text { GGAGTTGAAATAGATGAA- } \\
\text { CATGATCTG }\end{array}$ \\
\hline Syncytin-1 & ATGGAGCCCAAGATGCAG & AGATCGTGGGCTAGCAG \\
\hline
\end{tabular}

trophoblastic cells was determined by the RayBio $^{\circledR}$ Human Leptin ELISA Kit (RayBiotech, Norcross, GA, USA) according to the manufacturer's instructions. Lactate dehydrogenase (LDH) concentrations were obtained spectrophotometrically [36] by the In Vitro Toxicology Assay Kit Lactate Dehydrogenase based (TOX-7, SigmaAldrich). Determination of culture supernatant protein content for protein normalisation was performed with Pierce bicinchoninic acid (BCA) Protein Assay Reagent (Thermo Fisher Scientific, Bonn, Germany). All measurements were assayed in triplicate. Analysis of the results was performed using Ascent Software v2.6 for Multiscan photometer (Thermo Fisher Scientific).

\section{Statistical analysis}

Results were expressed as mean \pm standard error of the mean (SEM). Differences were assessed using the nonparametric Mann-Whitney $U$ test provided with SPSS statistic software (v19.001, IBM, Ehningen, Germany). A p-value of $<0.05$ was considered significant.

\section{Results}

\section{Assessment of primary trophoblastic cell viability and} functionality

At the sequential experimental time-points $\mathrm{LDH}$ was assessed spectrophotometrically using the trophoblastic cell supernatants. There was no significant increase observed during trophoblastic cell culture, nor were group differences detected between unstimulated controls and CRH-treated trophoblast cells in terms of viability (Table 2), ruling out a contamination of the supernatant with intracellular $\beta$-hCG as a consequence of cell lysis. The $\beta$-hCG secretion is a valid parameter of trophoblast syncytialisation rate [31]. The $\beta$-hCG content of the trophoblastic cell supernatant, as assessed by ELISA, increased continuously over the time-points investigated in both experimental groups. After $24 \mathrm{~h}$ of culture, the increase became significant $(\mathrm{p}<0.01)$ evidencing the progression of syncytialisation of the trophoblastic cells (data not shown). Compared to $6 \mathrm{~h}$, both vehicle and CRH treated primary trophoblastic cells

\begin{tabular}{|c|c|c|c|c|c|}
\hline \multirow[t]{3}{*}{ Time (hours) } & \multicolumn{4}{|c|}{ Absorbance levels (rel. units) } & \multirow[t]{3}{*}{$p$-value } \\
\hline & \multicolumn{2}{|c|}{ Vehicle } & \multicolumn{2}{|c|}{ CRH } & \\
\hline & mean & SEM & mean & SEM & \\
\hline 6 & 0.021 & 0.006 & 0.022 & 0.013 & ns \\
\hline 12 & 0.036 & 0.005 & 0.032 & 0.001 & ns \\
\hline 24 & 0.026 & 0.017 & -0.004 & 0.003 & ns \\
\hline 48 & 0.033 & 0.004 & 0.019 & 0.001 & ns \\
\hline 72 & 0.025 & 0.005 & 0.029 & 0.006 & ns \\
\hline
\end{tabular}


showed a significant increase of $\beta$-hCG protein content in the supernatant at $48 \mathrm{~h}(\mathrm{p}<0.01)$ and more significantly at $72 \mathrm{~h}(\mathrm{p}<0.001$, data not shown). Stimulation with $\mathrm{CRH} \quad(1.0$ and $2.0 \mu \mathrm{g} / \mathrm{ml})$ did not influence the amount of $\beta$-hCG in the supernatant at 48 and $72 \mathrm{~h}$ (Figure 1), indicating that $\mathrm{CRH}$ does not alter maturation of trophoblastic cells in vitro. Additionally we measured syncytin-1 (Syn1) expression, as previously described [33,35]. Syn1 is essential for mediating trophoblast cell fusion events [37]. Syn1 expression was significantly induced at $48 \mathrm{~h}$ by $\mathrm{CRH}$ in a dose-dependent manner $(1.0 \mu \mathrm{g}<2.0 \mu \mathrm{g}, \mathrm{p}<0.029$ for both, Figure 1$)$. At $72 \mathrm{~h}$ the

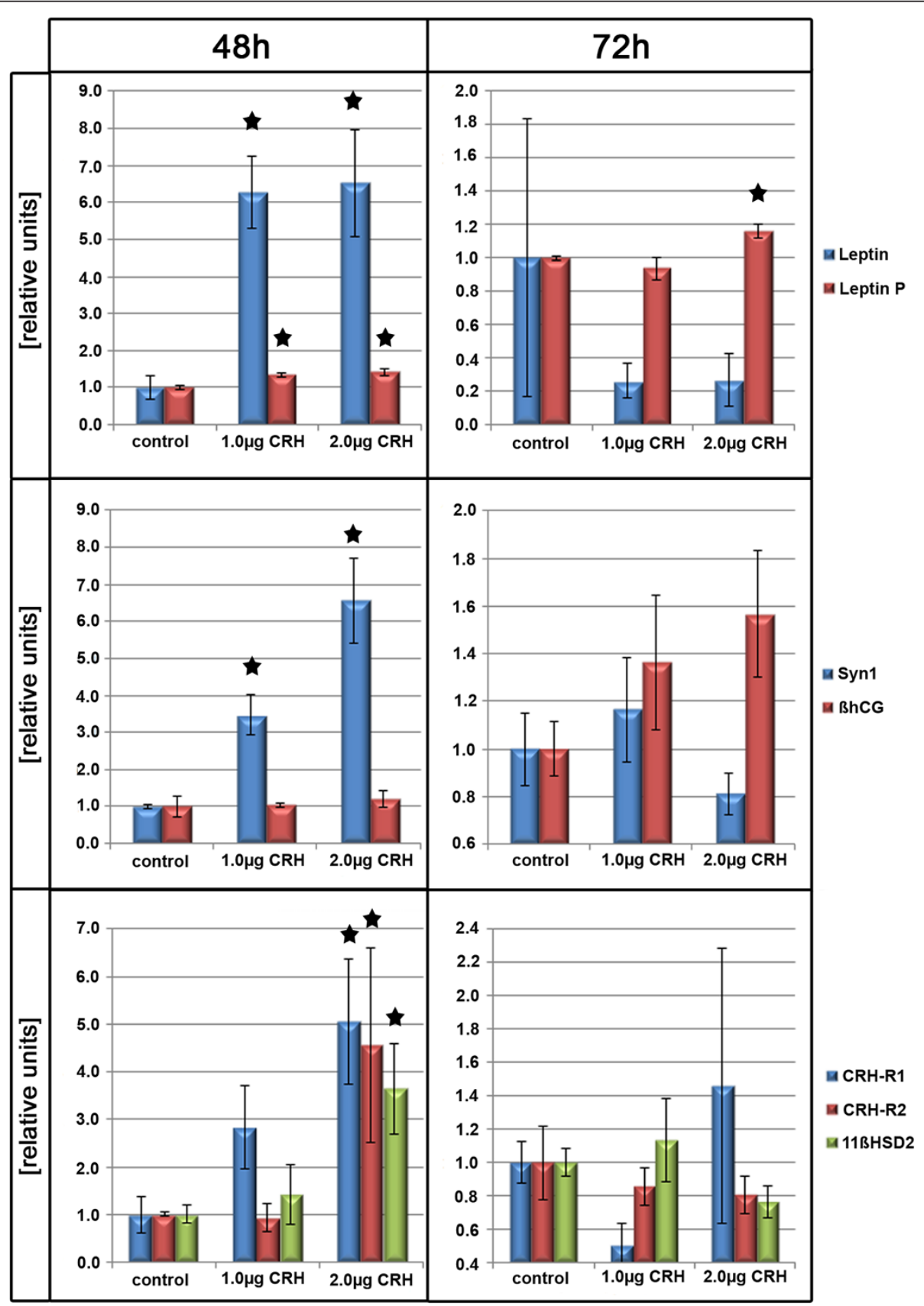

Figure 1 Overview of gene expression profiles and results of protein detection. Overview of gene expression profiles (RT-PCR) and results of protein detection (ELISA) in cell culture supernatant of vehicle and corticotropin-releasing hormone (CRH) $(1.0 \mathrm{and} 2.0 \mu \mathrm{g} / \mathrm{ml}) \mathrm{treated}$ trophoblasts at 48 and 72 h. Top row: Leptin gene expression (Leptin, blue bars), Leptin protein secretion (Leptin P, red bars). Middle row: Syncytin-1 (Syn1) (blue bars), $\beta$-hCG (red bars). Bottom row: CRH-R1 (blue bars), CRH-R2 (red bars), 11ß-HSD2 (green bars). Displayed are values relative to the control value at the designated time-point as mean $\pm \mathrm{SEM},{ }^{*}=p<0.05$. 
stimulative effect of CRH on Syn1 expression had subsided (Figure 1).

\section{Leptin expression}

Previous experiments have shown a close relation of trophoblast leptin expression to leptin secretion [14]. Leptin expression increased with culture time of trophoblastic cells, irrespective of the stimulation with $\mathrm{CRH}$. This increase was significant after $12 \mathrm{~h}$ of culture and peaked after $24 \mathrm{~h}$ (Figure 2; $\mathrm{p}<0.05$ ). While leptin expression levels in the unstimulated control group declined after $48 \mathrm{~h}, \mathrm{CRH}$-treated primary trophoblastic cells showed a more sustained induction of leptin expression (Figure 2). At this time-point, leptin expression was significantly higher in the trophoblastic cells after stimulation with 1.0 and $2.0 \mu \mathrm{g} / \mathrm{ml}$ CRH compared to unstimulated controls ( $p<0.05$, Figure 1 and Figure 2). After $72 \mathrm{~h}$ the leptin expression had returned to a basal level in both groups alike. Leptin protein expression closely matches expressional changes following $\mathrm{CRH}$ stimulation (Figure 1). At $48 \mathrm{~h} \mathrm{CRH}$ dose-dependently increased in leptin secretion into trophoblast culture supernatant. The stimulatory effect of $1.0 \mu \mathrm{g} / \mathrm{ml} \mathrm{CRH}$ on trophoblast leptin secretion lasted for $48 \mathrm{~h}(\mathrm{p}<0.029)$. After $2.0 \mu \mathrm{g} / \mathrm{ml} \mathrm{CRH} \mathrm{stimulation,} \mathrm{there} \mathrm{was} \mathrm{still} \mathrm{a} \mathrm{sig-}$ nificant $(\mathrm{p}<0.002)$ induction in leptin secretion detectable at $72 \mathrm{~h}$ (Figure 1).

\section{$11 \beta$-HSD2 expression}

Stimulation of trophoblastic cells with $2.0 \mu \mathrm{g} / \mathrm{ml} \mathrm{CRH}$ significantly $(\mathrm{p}<0.029)$ induced $11 ß-\mathrm{HSD}-2$ expression at $48 \mathrm{~h}$ (Figure 1). Stimulation of trophoblastic cells with $1.0 \mu \mathrm{g} / \mathrm{ml}$ CRH did not significantly alter $11 ß-H S D-2$ expression during the observational period (Figure 1).
At $72 \mathrm{~h}$ the stimulatory effect of $\mathrm{CRH}$ had subsided for both 1.0 and $2.0 \mu \mathrm{g} / \mathrm{ml} \mathrm{CRH}$ concentrations.

\section{$\mathrm{CRH}$ receptor expression}

CRH-R2 gene expression was low $\left(\mathrm{C}_{\mathrm{t}}: 32.8 \pm 0.35 \mathrm{SEM}\right)$ in cultured human trophoblasts throughout the duration of the experiment, while CRH-R1 was readily detectable $\left(C_{\mathrm{t}}: 24.89 \pm 0.21 \mathrm{SEM}\right) . \mathrm{CRH}$ treatment at a concentration of $2.0 \mu \mathrm{g} / \mathrm{ml}$ resulted in an increased CRH-R1 and CRH-R2 expression in these cells $(5.05 \pm 1.33$ SEM, $\mathrm{p}=0.029 ; 4.55 \pm 2.05$ SEM, $\mathrm{p}=0.029$, respectively). Interestingly, at $72 \mathrm{~h} \mathrm{CRH-R1}$ and CRH-R2 expression levels following $\mathrm{CRH}$ treatment $(1.0$ and $2.0 \mu \mathrm{g} / \mathrm{ml})$ were not different to expression levels in vehicle treated controls.

\section{Discussion}

In the present study, we aimed to clarify the influence of corticotropin-releasing hormone (CRH) exposure on the syncytialisation rate of isolated primary villous trophoblastic cells. Moreover, we investigated whether $\mathrm{CRH}$ induces alterations in gene expression of specific endocrine placental regulators in vitro. Our results showed a significantly higher leptin expression in trophoblastic cells, which concomitantly resulted in a significant induction of leptin protein secretion into the supernatant after $48 \mathrm{~h}$ of $\mathrm{CRH}$ stimulation, compared to unstimulated control cells. Moreover, 11 $\beta-H S D 2$ expression was dose-dependently induced by $2.0 \mu \mathrm{g} / \mathrm{ml} \mathrm{CRH}$ after $48 \mathrm{~h}$. Formation of a functional syncytiotrophoblast occurred after $24 \mathrm{~h}$ in the $\mathrm{CRH}$-stimulated and the control group to the same degree, as determined by increasing $\beta$-hCG secretion without a concomitant increase of cell lysis reflected by constant LDH levels in the supernatant throughout the experiment [31]. Syncytin-1 expression, a key regulator gene of trophoblast syncytialisation

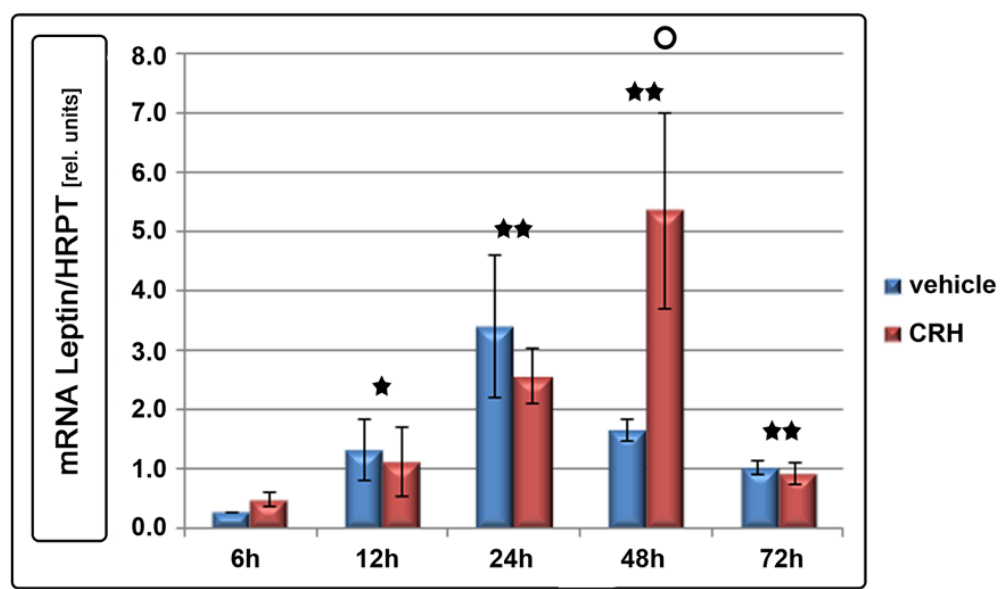

Figure 2 Leptin expression in human trophoblastic cells: Vehicle vs. CRH $(\mathbf{1 . 0} \boldsymbol{\mu g} / \mathbf{m l})$ stimulation. A significant $(p<0.05)$ increase in relative leptin gene expression was observed after $12 \mathrm{~h}$ in both groups. $\mathrm{CRH}$ treatment significantly $(\mathrm{p}<0.05$, circle) increased leptin expression above control levels after $48 \mathrm{~h}$. Gene expression is related to the housekeeping gene HPRT. Displayed are means \pm SEM, ${ }^{*} \mathrm{p}<0.05,{ }^{* *} \mathrm{p}<0.01$. 
$[33,35,37]$, was dose-dependently induced after $48 \mathrm{~h}$ of $\mathrm{CRH}$ stimulation only.

The finding that leptin expression increases with the progression of trophoblast syncytialisation in both groups is in line with results from Ashworth et al. [38], who showed that placental leptin expression is an exclusive feature of the syncytiotrophoblast (SCT), with a reduced leptin expression in undifferentiated cytotrophoblasts. Likewise, CRH was described as a syncytical peptide [39]. CRH-treated and vehicle stimulated trophoblasts showed an equal increase of $ß-\mathrm{hCG}$ concentration in the culture supernatant, while cell lysis was low and not different (as determined by LDH). This finding is indicative that the rate of trophoblast syncytialisation gradually increased over time in both groups [40]. The induction of leptin expression after $24 \mathrm{~h}$ of culture of CRH- and vehicle treated trophoblastic cells can therefore be attributed to trophoblastic differentiation into functional syncytium. The significant difference in leptin gene expression in CRH-treated and vehicle treated control groups at $48 \mathrm{~h}$ and the induction of leptin protein secretion into the cell culture supernatant, however, do not seem to be solely an indirect effect of syncytialisation, as $\mathrm{B}$-hCG levels of CRHtreated trophoblastic cells were not significantly different from the $\mathrm{B}$-hCG levels of vehicle treated controls. Hence the significant increase in leptin expression and secretion of stimulated cells at $48 \mathrm{~h}$ rather seems to be a direct effect of $\mathrm{CRH}$, possibly via activation of $\mathrm{CRH}-\mathrm{R} 1 \alpha$, which was readily detectable in trophoblasts $[10,41]$ and towards which $\mathrm{CRH}$ shows a ten times higher affinity as compared to CRH-R2 [42], whose expression was significantly lower. The fact that we were able to detect CRH$\mathrm{R} 1 \alpha$ and $\mathrm{CRH}-\mathrm{R} 2$ in vitro does not rule out the possibility of CRH signalling via its other known placental isoforms that were described in vivo $[10,41]$. Interestingly Karteris et al. found significant levels of receptor hybridization foremost in syncytiotrophoblast and to a lesser extend in scattered cytotrophoblasts, which is supported by almost exclusive binding of $\left[{ }^{125} \mathrm{I}\right] \mathrm{CRH}$ to purified syncytiotrophoblast [43]. This could suggest CRH might rather excert its functions after spontaneous syncytialisation of cytotrophoblasts in vitro than on single cytotrophoblasts.

To address the functional relevance of our findings studies with $\mathrm{CRH}$ antagonists, such as $\mathrm{CRH}$ antagonists antalarmin (CRH-R1) and antisauvagine (CRH-R2) would be needed.

We found that CRH $(2 \mu \mathrm{g} / \mathrm{ml})$ dose-dependently induced $\mathrm{CRH}-\mathrm{R} 1 \alpha$ and $-\mathrm{R} 2$ gene expression at $48 \mathrm{~h}$ (Figure 1, p < 0.029). The stimulatory effect of $\mathrm{CRH}$ on leptin expression was abolished at $72 \mathrm{~h}$. CRH-R internalization could be a possible mechanism to explain this phenomenon, as previously described by others
$[44,45]$. CRH-R internalization could also account for the absence of an expressional effect on the studied target genes following repeated $\mathrm{CRH}$ stimulation in our pilot study. Such an induction of CRH-R expression levels following exposure to higher doses of CRH might optimize $\mathrm{CRH}$ signal transduction. Interestingly, higher concentrations of $\mathrm{CRH}(2.0 \mu \mathrm{g} / \mathrm{ml})$ also significantly induced 11ß-HSD2 expression at $48 \mathrm{~h}$ (Figure 1, $\mathrm{p}<0.029)$, while $1.0 \mu \mathrm{g} / \mathrm{ml}$ showed no such effect. Hence higher levels of auto-/paracrine CRH might hypothetically prepare the syncytium to cope with a CRH-triggered increase of maternal cortisol more efficiently.

The above findings regarding leptin are in line with findings from our previous experiments showing a close relationship of trophoblast leptin expression and secretion rate in vitro following dexamethasone stimulation [14]. Interestingly, dexamethasone stimulation $(10 \mu \mathrm{M})$ produced a more pronounced leptin secretion $(\sim 120 \mathrm{pg} / \mathrm{ml}$ at $72 \mathrm{~h})$ when compared to $\mathrm{CRH}(1.0$ and $2.0 \mu \mathrm{g} / \mathrm{ml})$ stimulation ( $56-61 \mathrm{pg} / \mathrm{ml}$ at $72 \mathrm{~h}$, respectively). However, dexamethasone clearly induced $\mathrm{B}$-hCG secretion. Hence in contrast to $\mathrm{CRH}$ the effect of dexamethasone on leptin secretion seems to be partly attributable to an increased rate of trophoblast differentiation and maturation, as also seen by Audette et al. [46]. They were also able to demonstrate a trend to Syn1 induction in placental explants following dexamethasone treatment.

The fact, that we found an increase in Syn 1 expression following $\mathrm{CRH}$ stimulation without a concomitant increase in $\mathrm{B}$-hCG might point to a differential regulation of the two genes. A common pathway for both Syn1 and ß-hCG stimulation is the forskolin triggered induction of cAMP [47]: An activation of adenyl cyclase (AC) raises intracellular cAMP levels and leads to PKA activation via interactions with AKAPs and downstream phosphorylation of p38MAPK and ERK1/2. Accordingly, $\mathrm{CRH}$ was found to induce cAMP in human endometrium via CRHR1 triggered protein-kinase A (PKA) [48] and we recently found that Syn 1 is induced via the cAMP pathway in endometrial carcinoma [49]. However, as $ß$-hCG was not induced, CRH might either use alternative signalling pathways, such as signalling via PKC $[45,50]$, or the detected Syn 1 expression might come from a source other than the cytotrophoblast. However our cytotrophoblast isolation is $\sim 90 \%$ pure. Thus, we cannot exclude possible minor fractions of extravillous trophoblasts (EVT) in our cell culture. EVT express CRHR1 [51] and show Syn1 expression [20,52]. Therefore, we cannot completely rule out that the Syn 1 induction measured is derived from EVT. But due to their extremely small fraction in the isolation, a six-fold increase in Syn1 expression by EVT following CRHstimulation seems rather unlikely. Another explanation could be, that $\mathrm{CRH}$ fosters maintenance fusion events 
instead of functional fusion processes, that would be reflected in ß-hCG secretion. Importantly, Syn1 is related to trophoblast processes beyond its fusogenic nature. Possible functions of the syncytin proteins are suppression of the maternal immune response against the developing fetus [53] and induction of placental immunity against vertical transmission of retroviral infections [54]. We observed a stimulatory effect of CRH $(2.0 \mu \mathrm{g} / \mathrm{ml}$ after $48 \mathrm{~h}$ ) on the expression of 11ß-HSD2 in primary cultured cytotrophoblasts. Like leptin, the induction of $11 \beta-H S D 2$ by CRH subsided at $72 \mathrm{~h}$, possibly due to $\mathrm{CRH}$-receptor internalization, as discussed above. In a previous study using the same in vitro setup, we were able to show that dexamethasone $(10 \mu \mathrm{M})$ similarly stimulates both leptin and 11/-HSD2 expression in primary trophoblastic cells [14]. 11ß-HSD2 gene expression in human placental trophoblasts grown in primary culture has been shown to maintain the same pattern as in vivo [55] and dexamethasone stimulation regularly results in an increase in $11 ß-H S D 2$ protein expression in trophoblasts [56]. Upon the finding that $\mathrm{CRH}$ induces $11 \beta$ HSD2 expression one cannot draw conclusions about the activity of placental glucocorticoid metabolism. Interestingly, Friedberg et al. [57] found a CRH-induced reduction of 11ß-HSD1 activity in human adipocytes in vitro. In isolated cytotrophoblasts Sharma et al. [58] were unable to induce $11 ß-H S D 2$ activity using CRH concentrations of $1-100 \mathrm{ng} / \mathrm{ml}$, however, they were able to identify the $\mathrm{CRH}$ downstream signalling protein p38MAPK [47] as an essential regulator for 11ß-HSD2 activity. The fact, that we observed expressional changes of $11 \beta$-HSD2 following CRH treatment at much higher CRH dosages $(2.0 \mu \mathrm{g} / \mathrm{ml})$ could however imply a possibility of a CRH-driven glucocorticoid induced feed-forward mechanism on 11ß-HSD2 activity. Although such a mechanism has not been described for the placenta yet, the subsequent reduction of cortisol availability might be an intriguing regulatory function shielding the fetus of placental CRH-induced maternal glucocorticoids.

Our study focused on the auto- and paracrine effects of $\mathrm{CRH}$ on leptin production in isolated trophoblasts, as the placenta co-expresses both leptin (ObR-L) [59] and $\mathrm{CRH}$ receptors [9]. We were able to show a significant increase in leptin expression in syncytialised trophoblastic cells following CRH treatment. While the exact auto- and paracrine mechanisms and the functional role of the interaction of $\mathrm{CRH}$ and leptin at the level of the syncytiotrophoblast remain to be determined, an increase of endocrine $\mathrm{CRH}$ and leptin expression might translate into endocrine signals affecting both fetus and mother, besides their local influence on the trophoblast.

In this respect it is noteworthy, that the major fraction of placental leptin and $\mathrm{CRH}$ is secreted into the maternal circulation $[60,61]$. Nevertheless, the syncytiotrophoblast is also involved in the maintenance of fetal leptin and CRH serum levels $[62,63]$. Besides its role in fetal organ maturation via cortisol induction, there is in fact evidence, that placental CRH drives parturition via induction of adrenal DHEA-S on the fetal side followed by an increase in placental estrogen secretion [63].

In IUGR, a condition characterised by increased fetal serum CRH levels [25], we found unchanged leptin levels in fetal umbilical cord blood [23], despite an elevated placental leptin mRNA and protein expression $[28,64]$. Hence, it seems likely that CRH and CRHinduced leptin (as suggested by our results) might interact on the maternal side.

White et al. [65] showed that leptin has lipolytic effects in rat placental tissue in vitro. CRH antagonises lipolysis via down-regulation of 11ß-HSD1 in adipose tissue [57]. Hypothetically leptin and CRH might act together in regulating the maintenance of fetal nutrient supply at the placental level.

\section{Conclusions}

In summary, our data indicate that $\mathrm{CRH}$ stimulation induces leptin secretion in the human syncytiotrophoblast in an auto-/paracrine fashion. Similarly, CRH induced 11ß-HSD2 expression. This suggests a short-loop feedback of $\mathrm{CRH}$-induced leptin on $\mathrm{CRH}$ action at the fetomaternal interface. Such a putative cross-talk could play an essential role in the regulation of syncytiotrophoblast nutrient supply and cortisol metabolism, besides possible further implications for myometrial contractility, placental bed perfusion and the timing of birth. Furthermore CRHinduced 11ß-HSD2 might locally determine placental corticosteroid metabolism and thereby the passage of placental CRH-triggered maternal cortisol via the syncytium to the fetus. This would protect the fetus from detrimental elevated maternal glucocorticoid exposure. The underlying mechanism and the functional role of the interaction of CRH with leptin and 11ß-HSD2 at the syncytiotrophoblast remain to be determined.

\section{Competing interests}

The authors declare that they have no competing interests.

\section{Authors' contributions}

FBF contributed to conception and design of the study, analysed and interpreted the data and drafted the manuscript. MR performed the cell culture experiments, including RT-PCRs. GV performed ELISA analysis. RO contributed to acquisition and analysis of the data, $\mathrm{AH}$ contributed to interpretation of data and was involved in drafting the manuscript, MR and $\mathrm{CM}-\mathrm{C}$ were involved in the analysis of data and critically revised the manuscript for important intellectual content, RS contributed to the acquisition and analysis of data, WR critically revised the manuscript for important intellectual content, JD contributed to the conception and design of the study and critically revised the manuscript for important intellectual content. All authors have given the final approval of the version to be published. 


\section{Acknowledgements}

The authors thank Novo Nordisk (Investigator initiated research grant) and the "Deutsche Forschungsgemeinschaft" (STR 923/1-1) for financial support. We thank Ms. Bitterer and Mr. Wachtveitl for technical assistance. We also thank the research staff of the Department of Gynecology and Obstetrics, University of Erlangen, especially Mrs. Oeser, for their collaboration. The study sponsors had no involvement in the collection, analysis and interpretation of data, in the writing of the manuscript and in the decision to submit the manuscript for publication.

\section{Author details}

'Department of Pediatrics and Adolescent Medicine, University of Erlangen-Nürnberg, Erlangen, Germany. ${ }^{2}$ Department of Gynecology and Obstetrics, University of Erlangen-Nürnberg, Erlangen, Germany. ${ }^{3}$ Childrens' and Adolescents' Hospital, University of Cologne, Cologne, Germany.

Received: 13 January 2012 Accepted: 4 September 2012 Published: 12 September 2012

\section{References}

1. Shibasaki T, Odagiri E, Shizume K, Ling N: Corticotropin-releasing factorlike activity in human placental extracts. J Clin Endocrinol Metab 1982, 55:384-386

2. Petraglia F, Florio P, Gallo R, Simoncini T, Saviozzi M, Di Blasio AM, Vaughan J, Vale W: Human placenta and fetal membranes express human urocortin mRNA and peptide. J Clin Endocrinol Metab 1996, 81:3807-3810.

3. Kalantaridou SN, Makrigiannakis A, Mastorakos G, Chrousos GP: Roles of reproductive corticotropin-releasing hormone. Ann N Y Acad Sci 2003, 997:129-135

4. McLean M, Smith R: Corticotropin-releasing Hormone in Human Pregnancy and Parturition. Trends Endocrinol Metab 1999, 10:174-178

5. Mastorakos G, Scopa CD, Vryonidou A, Friedman TC, Kattis D, Phenekos C, Merino MJ, Chrousos GP: Presence of immunoreactive corticotropinreleasing hormone in normal and polycystic human ovaries. J Clin Endocrinol Metab 1994, 79:1191-1197.

6. Di Blasio AM, Pecori Giraldi F, Vigano P, Petraglia F, Vignali M, Cavagnini F: Expression of corticotropin-releasing hormone and its R1 receptor in human endometrial stromal cells. $J$ Clin Endocrinol Metab 1997 82:1594-1597.

7. Petraglia F, Tabanelli S, Galassi MC, Garuti GC, Mancini AC, Genazzani AR, Gurpide E: Human decidua and in vitro decidualized endometrial stromal cells at term contain immunoreactive corticotropin-releasing factor (CRF) and CRF messenger ribonucleic acid. J Clin Endocrinol Metab 1992, 74:1427-1431.

8. Rodriguez-Linares B, Linton EA, Phaneuf S: Expression of corticotrophinreleasing hormone receptor mRNA and protein in the human myometrium. J Endocrinol 1998, 156:115-21.

9. Gao L, He P, Sha J, Liu C, Dai L, Hui N, Ni X: Corticotropin-releasing hormone receptor type 1 and type 2 mediate differential effects on 15-hydroxy prostaglandin dehydrogenase expression in cultured human chorion trophoblasts. Endocrinology 2007, 148:3645-3654.

10. Karteris E, Grammatopoulos D, Dai Y, Olah KB, Ghobara TB, Easton A, Hillhouse EW: The human placenta and fetal membranes express the corticotropin-releasing hormone receptor 1alpha (CRH-1alpha) and the CRH-C variant receptor. J Clin Endocrinol Metab 1998, 83:1376-1379.

11. Lockwood CJ, Radunovic N, Nastic D, Petkovic S, Aigner S, Berkowitz GS: Corticotropin-releasing hormone and related pituitary-adrenal axis hormones in fetal and maternal blood during the second half of pregnancy. J Perinat Med 1996, 24:243-251.

12. Grammatopoulos D, Dai Y, Chen J, Karteris E, Papadopoulou N, Easton AJ, Hillhouse EW: Human corticotropin-releasing hormone receptor: differences in subtype expression between pregnant and nonpregnant myometria. J Clin Endocrinol Metab 1998, 83:2539-2544.

13. Stevens MY, Challis JR, Lye SJ: Corticotropin-releasing hormone receptor subtype 1 is significantly up-regulated at the time of labor in the human myometrium. J Clin Endocrinol Metab 1998, 83:4107-4115.

14. Tzschoppe A, Fahlbusch F, Seidel J, Dorr HG, Rascher W, Goecke TW, Beckmann MW, Schild RL, Struwe E, Dotsch J: Dexamethasone stimulates the expression of leptin and 11beta-HSD2 in primary human placental trophoblastic cells. Eur J Obstet Gynecol Reprod Biol 2011, 156(1):50-55. Epub 2011 Feb 2.
15. van Beek JP, Guan H, Julan L, Yang K: Glucocorticoids stimulate the expression of 11 beta-hydroxysteroid dehydrogenase type 2 in cultured human placental trophoblast cells. J Clin Endocrinol Metab 2004, 89:5614-5621.

16. Grammatopoulos DK, Hillhouse EW: Role of corticotropin-releasing hormone in onset of labour. Lancet 1999, 354:1546-1549.

17. Tyson EK, Smith R, Read M: Evidence that corticotropin-releasing hormone modulates myometrial contractility during human pregnancy. Endocrinology 2009, 150:5617-5625.

18. Aggelidou E, Hillhouse EW, Grammatopoulos DK: Up-regulation of nitric oxide synthase and modulation of the guanylate cyclase activity by corticotropin-releasing hormone but not urocortin II or urocortin III in cultured human pregnant myometrial cells. Proc Natl Acad Sci U S A 2002, 99:3300-3305

19. Clifton VL, Read MA, Leitch IM, Giles WB, Boura AL, Robinson PJ, Smith R: Corticotropin-releasing hormone-induced vasodilatation in the human fetal-placental circulation: involvement of the nitric oxide-cyclic guanosine 3',5'-monophosphate-mediated pathway. J Clin Endocrinol Metab 1995, 80:2888-2893.

20. Bamberger AM, Minas V, Kalantaridou SN, Radde J, Sadeghian H, Loning T, Charalampopoulos I, Brummer J, Wagener C, Bamberger CM, et al: Corticotropin-releasing hormone modulates human trophoblast invasion through carcinoembryonic antigen-related cell adhesion molecule-1 regulation. Am J Pathol 2006, 168:141-150.

21. Kadyrov M, Kingdom JC, Huppertz B: Divergent trophoblast invasion and apoptosis in placental bed spiral arteries from pregnancies complicated by maternal anemia and early-onset preeclampsia/intrauterine growth restriction. Am J Obstet Gynecol 2006, 194:557-563.

22. Roberts JM, Taylor RN, Musci TJ, Rodgers GM, Hubel CA, McLaughlin MK Preeclampsia: an endothelial cell disorder. Am J Obstet Gynecol 1989, 161:1200-1204.

23. Tzschoppe AA, Struwe E, Dorr HG, Goecke TW, Beckmann MW, Schild RL, Dotsch J: Differences in gene expression dependent on sampling site in placental tissue of fetuses with intrauterine growth restriction. Placenta 2010, 31:178-185.

24. Dotsch J, Nusken KD, Knerr I, Kirschbaum M, Repp R, Rascher W: Leptin and neuropeptide $Y$ gene expression in human placenta: ontogeny and evidence for similarities to hypothalamic regulation. J Clin Endocrinol Metab 1999, 84:2755-2758.

25. Goland RS, Jozak S, Warren WB, Conwell IM, Stark RI, Tropper PJ: Elevated levels of umbilical cord plasma corticotropin-releasing hormone in growth-retarded fetuses. J Clin Endocrinol Metab 1993, 77:1174-1179.

26. Goland RS, Tropper PJ, Warren WB, Stark RI, Jozak SM, Conwell IM: Concentrations of corticotrophin-releasing hormone in the umbilicalcord blood of pregnancies complicated by pre-eclampsia. Reprod Fertil Dev 1995, 7:1227-1230

27. Ruebner M, Strissel PL, Langbein M, Fahlbusch F, Wachter DL, Faschingbauer F, Beckmann MW, Strick R: Impaired cell fusion and differentiation in placentae from patients with intrauterine growth restriction correlate with reduced levels of HERV envelope genes. J Mol Med 2010, 88:1143-1156.

28. McCarthy C, Cotter FE, McElwaine S, Twomey A, Mooney EE, Ryan F, Vaughan J: Altered gene expression patterns in intrauterine growth restriction: potential role of hypoxia. Am J Obstet Gynecol 2007, 196(70):e71-e76.

29. Dy J, Guan H, Sampath-Kumar R, Richardson BS, Yang K: Placental 11 betahydroxysteroid dehydrogenase type 2 is reduced in pregnancies complicated with idiopathic intrauterine growth Restriction: evidence that this is associated with an attenuated ratio of cortisone to cortisol in the umbilical artery. Placenta 2008, 29:193-200.

30. Voigt M, Schneider KT, Jahrig K: Analysis of a 1992 birth sample in Germany 1: New percentile values of the body weight of newborn infants. Geburtshilfe Frauenheilkd 1996, 56:550-558.

31. Kliman HJ, Nestler JE, Sermasi E, Sanger JM, Strauss JF 3rd: Purification, characterization, and in vitro differentiation of cytotrophoblasts from human term placentae. Endocrinology 1986, 118:1567-1582.

32. Schild RL, Sonnenberg-Hirche CM, Schaiff WT, Bildirici I, Nelson DM, Sadovsky $Y$ : The kinase $\mathrm{p} 38$ regulates peroxisome proliferator activated receptor-gamma in human trophoblasts. Placenta 2006, 27:191-199.

33. Ruebner M, Strissel PL, Langbein M, Fahlbusch F, Wachter DL, Faschingbauer F, Beckmann MW, Strick R: Impaired cell fusion and 
differentiation in placentae from patients with intrauterine growth restriction correlate with reduced levels of HERV envelope genes. J Mol Med (Berl) 2010, 88:1143-1156.

34. Guilbert LJ, Winkler-Lowen B: Placental alkaline phosphatase (PLAP) staining and human chorionic gonadotropin (hCG) production in cultures of fresh and cryopreserved cytotrophoblasts isolated by CD9/ MHC class I/MHC class II immunoelimination. Placenta 2007, 28:348-349.

35. Ruebner M, Langbein M, Strissel PL, Henke C, Schmidt D, Goecke TW, Faschingbauer F, Schild RL, Beckmann MW, Strick R: Regulation of the human endogenous retroviral Syncytin-1 and cell-cell fusion by the nuclear hormone receptors PPARgamma/RXRalpha in placentogenesis. J Cell Biochem 2012, 113:2383-2396.

36. Legrand C, Bour JM, Jacob C, Capiaumont J, Martial A, Marc A, Wudtke M, Kretzmer G, Demangel C, Duval D, et al: Lactate dehydrogenase (LDH) activity of the cultured eukaryotic cells as marker of the number of dead cells in the medium [corrected]. J Biotechnol 1992, 25:231-243.

37. Mallet F, Bouton O, Prudhomme S, Cheynet V, Oriol G, Bonnaud B, Lucotte G, Duret L, Mandrand B: The endogenous retroviral locus ERVWE1 is a bona fide gene involved in hominoid placental physiology. Proc Natl Acad Sci U S A 2004, 101:1731-1736.

38. Ashworth CJ, Hoggard N, Thomas L, Mercer JG, Wallace JM, Lea RG: Placental leptin. Rev Reprod 2000, 5:18-24.

39. Riley SC, Walton JC, Herlick JM, Challis JR: The localization and distribution of corticotropin-releasing hormone in the human placenta and fetal membranes throughout gestation. J Clin Endocrinol Metab 1991, 72:1001-1007.

40. Watson AL, Palmer ME, Burton G: Human chorionic gonadotrophin release and tissue viability in placental organ culture. Hum Reprod 1995, 10:2159-2164

41. Florio P, Franchini A, Reis FM, Pezzani I, Ottaviani E, Petraglia F: Human placenta, chorion, amnion and decidua express different variants of corticotropin-releasing factor receptor messenger RNA. Placenta 2000, 21:32-37.

42. Perrin $\mathrm{MH}$, Vale $\mathrm{WW}$ : Corticotropin releasing factor receptors and their ligand family. Ann N Y Acad Sci 1999, 885:312-328.

43. Hatzoglou A, Margioris AN, Bakogeorgou E, Gravanis A, Castanas E: Identification, characterization and localization of corticotropin-releasing hormone receptors in human placenta. Life Sci 1996, 59:1871-1879.

44. Seres J, Bornstein SR, Seres P, Willenberg HS, Schulte KM, Scherbaum WA, Ehrhart-Bornstein M: Corticotropin-releasing hormone system in human adipose tissue. J Clin Endocrinol Metab 2004, 89:965-970.

45. Markovic D, Papadopoulou N, Teli T, Randeva H, Levine MA, Hillhouse EW, Grammatopoulos DK: Differential responses of corticotropin-releasing hormone receptor type 1 variants to protein kinase $C$ phosphorylation. J Pharmacol Exp Ther 2006, 319:1032-1042.

46. Audette MC, Greenwood SL, Sibley CP, Jones CJ, Challis JR, Matthews SG, Jones RL: Dexamethasone stimulates placental system A transport and trophoblast differentiation in term villous explants. Placenta 2010, 31:97-105.

47. Delidaki M, Gu M, Hein A, Vatish M, Grammatopoulos DK: Interplay of CAMP and MAPK pathways in hCG secretion and fusogenic gene expression in a trophoblast cell line. Mol Cell Endocrinol 2011, 332:213-220.

48. Graziani G, Tentori L, Portarena I, Barbarino M, Tringali G, Pozzoli G, Navarra P: $\mathrm{CRH}$ inhibits cell growth of human endometrial adenocarcinoma cells via $\mathrm{CRH}$-receptor 1-mediated activation of cAMP-PKA pathway. Endocrinology 2002, 143:807-813.

49. Strick R, Ackermann S, Langbein M, Swiatek J, Schubert SW, Hashemolhosseini S, Koscheck T, Fasching PA, Schild RL, Beckmann MW, Strissel PL: Proliferation and cell-cell fusion of endometrial carcinoma are induced by the human endogenous retroviral Syncytin- 1 and regulated by TGF-beta. J Mol Med (Berl) 2007, 85:23-38.

50. Dermitzaki I, Tsatsanis C, Alexaki VI, Castanas E, Margioris AN: Roles of protein kinase $\mathrm{A}$ (PKA) and PKC on corticotropin-releasing hormone (CRH)-induced elevation of cytosolic calcium from extra-and intracellular sources. Hormones (Athens) 2004, 3:252-258.

51. Kalantaridou SN, Zoumakis E, Makrigiannakis A, Godoy H, Chrousos GP: The role of corticotropin-releasing hormone in blastocyst implantation and early fetal immunotolerance. Horm Metab Res 2007, 39:474-477.

52. Kammerer U, Germeyer A, Stengel S, Kapp M, Denner J: Human endogenous retrovirus $\mathrm{K}(\mathrm{HERV}-\mathrm{K})$ is expressed in villous and extravillous cytotrophoblast cells of the human placenta. J Reprod Immunol 2011, 91:1-8.

53. Mangeney M, Renard M, Schlecht-Louf G, Bouallaga I, Heidmann O, Letzelter C, Richaud A, Ducos B, Heidmann T: Placental syncytins: Genetic disjunction between the fusogenic and immunosuppressive activity of retroviral envelope proteins. Proc Natl Acad Sci U S A 2007, 104:20534-20539.

54. Ponferrada VG, Mauck BS, Wooley DP: The envelope glycoprotein of human endogenous retrovirus HERV-W induces cellular resistance to spleen necrosis virus. Arch Virol 2003, 148:659-675.

55. Sun K, Yang K, Challis JR: Differential regulation of 11 beta-hydroxysteroid dehydrogenase type 1 and 2 by nitric oxide in cultured human placental trophoblast and chorionic cell preparation. Endocrinology 1997, 138:4912-4920.

56. Li JN, Ge YC, Yang Z, Guo CM, Duan T, Myatt L, Guan H, Yang K, Sun K: The $\mathrm{Sp} 1$ transcription factor is crucial for the expression of 11 betahydroxysteroid dehydrogenase type 2 in human placental trophoblasts. J Clin Endocrinol Metab 2011, 96:E899-E907.

57. Friedberg M, Zoumakis E, Hiroi N, Bader T, Chrousos GP, Hochberg Z: Modulation of 11 beta-hydroxysteroid dehydrogenase type 1 in mature human subcutaneous adipocytes by hypothalamic messengers. J Clin Endocrinol Metab 2003, 88:385-393.

58. Sharma A, Guan H, Yang K: The p38 mitogen-activated protein kinase regulates 11 beta-hydroxysteroid dehydrogenase type 2 (11 beta-HSD2) expression in human trophoblast cells through modulation of 11 betaHSD2 messenger ribonucleic acid stability. Endocrinology 2009, 150:4278-4286.

59. Bodner J, Ebenbichler CF, Wolf HJ, Muller-Holzner E, Stanzl U, Gander R, Huter O, Patsch JR: Leptin receptor in human term placenta: in situ hybridization and immunohistochemical localization. Placenta 1999, 20:677-682.

60. Linnemann K, Malek A, Sager R, Blum WF, Schneider H, Fusch C: Leptin production and release in the dually in vitro perfused human placenta. J Clin Endocrinol Metab 2000, 85:4298-4301.

61. Senaris R, Garcia-Caballero T, Casabiell X, Gallego R, Castro R, Considine RV, Dieguez C, Casanueva FF: Synthesis of leptin in human placenta. Endocrinology 1997, 138:4501-4504.

62. Ertl T, Funke S, Sarkany I, Szabo I, Rascher W, Blum WF, Sulyok E: Postnatal changes of leptin levels in full-term and preterm neonates: their relation to intrauterine growth, gender and testosterone. Biol Neonate 1999, 75:167-176.

63. Smith R, Mesiano S, Chan EC, Brown S, Jaffe RB: Corticotropin-releasing hormone directly and preferentially stimulates dehydroepiandrosterone sulfate secretion by human fetal adrenal cortical cells. J Clin Endocrinol Metab 1998, 83:2916-2920.

64. McMinn J, Wei M, Schupf N, Cusmai J, Johnson EB, Smith AC, Weksberg R, Thaker HM, Tycko B: Unbalanced placental expression of imprinted genes in human intrauterine growth restriction. Placenta 2006, 27:540-549.

65. White V, Gonzalez E, Capobianco E, Pustovrh C, Martinez N, Higa R, Baier M, Jawerbaum A: Leptin modulates nitric oxide production and lipid metabolism in human placenta. Reprod Fertil Dev 2006, 18:425-432

\section{doi:10.1186/1477-7827-10-80}

Cite this article as: Fahlbusch et al:: Corticotropin-releasing hormone stimulates expression of leptin, 11 beta-HSD2 and syncytin-1 in primary human trophoblasts. Reproductive Biology and Endocrinology 2012 10:80. 